\title{
Historein
}

Vol 16, No 1-2 (2017)

Greek Historiography in the 20th Century: Opening a Research Agenda

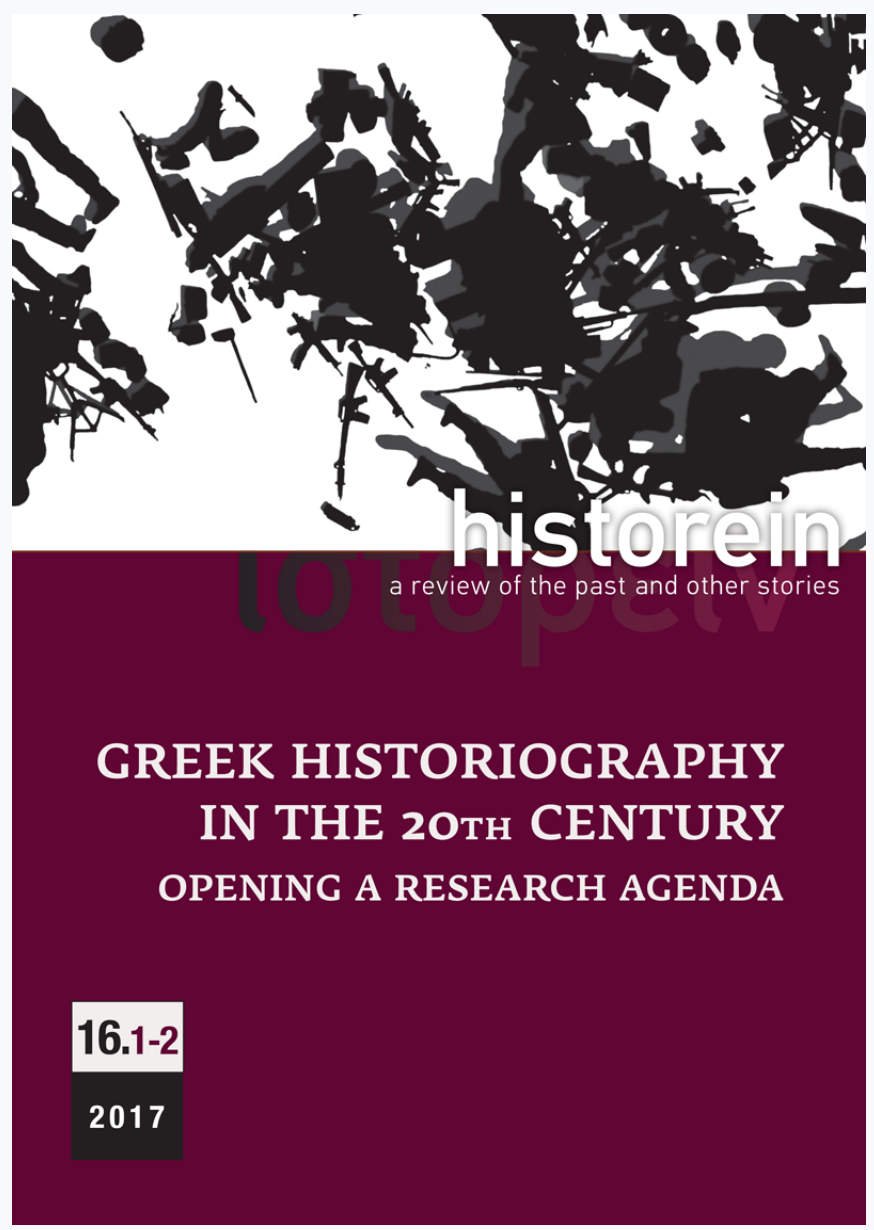

The First World War and the refugee crisis: historiography and memory in the Greek context

Emilia Salvanou

doi: $\underline{10.12681 / \text { historein.10027 }}$

Copyright @ 2017, Emilia Salvanou

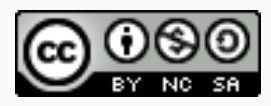

This work is licensed under a Creative Commons Attribution-NonCommercialShareAlike 4.0.

To cite this article:

Salvanou, E. (2017). The First World War and the refugee crisis: historiography and memory in the Greek context. Historein, 16(1-2), 120-138. https://doi.org/10.12681/historein.10027 


\section{The First \\ World War and the refugee crisis: historiography and memory in the Greek context}

Emilia Salvanou

Hellenic Open University
The First World War is at the core of most national historiographical narratives, including those of many European countries, the US, Australia and New Zealand. Its centenary has proven that it is a global event. ${ }^{1}$ Nevertheless, is the same event commemorated on the spectrum of the respective national narratives? A close examination of different national narratives that have developed around the Great War suggests that it may be more accurate to speak of a range of "great wars" that were fought in the 1910s rather than of a single, homogenous event that was understood, received and, most importantly, remembered in the same way by all the groups involved.

In Greece, one of the major consequences of the First World War was the Greek-Turkish War of 1919-1922, the disaster in Asia Minor and the ensuing refugee crisis. It is a memory that has overshadowed the memory of the Great War, serving as a lens through which both the events that preceded and proceeded the military defeat of 1922 were interpreted. The evacuation of the Greek population of Asia Minor in 1922 is one of the main lieux de memoire in the Greek national narrative. Asia Minor refugees are perceived as the archetypical victims of a supposed primordial Greek-Turkish enmity - a concept deeply woven into the founding myths of the Greek nation - that culminated after Greece's defeat in Anatolia. The way they are constructed historiographically does not differ very much: they are contextualised within the framework of Greece's campaign in Asia Minor in 1919, the ensuing Greek-Turkish War and Greece's military defeat. In other words, Asia Minor refugees are perceived as part of an autonomous episode in Greek national history, the outcome of which - military defeat and the uprooting of the Asia 
Minor Greek communities - is attributed mainly to the abandonment of Greece by its allies after the royalist victory in the 1920 elections. By being confined to the margins of national history, Asia Minor refugees are placed in a void, without any reference to the extended population movements that took place all over Europe or to the series of refugee waves from the Ottoman empire to Greece that became systematised after 1914. ${ }^{2}$ The same holds true for the period that followed. In the context of Greek historiography, the reception of the Asia Minor refugees is presented as an epic achievement of the Greek state - perhaps the most important one in peacetime. This narrative, though, obscures the fact that, during the interwar, refugees were constructed as distinct social subjects all over Europe and that they dynamically interrelated with the managing policies of the receiving states. The aim of this article is to examine the historiographical construction of Asia Minor refugees in the context of Greek historiography. It will not focus solely on historiography, though. Historiography neither reflects nor represents the past, but constructs it in a way that is meaningful for the present; it is subject to reinterpretations and rearticulations. Most importantly, it becomes a field of power antagonisms related to the spaces and trajectories of representations. Therefore, alongside the mainstream historiographical configurations of the issue under discussion, we will take under consideration the agency of the refugees, the strategies they developed and the paths they followed so as to ensure a space for their experience in the historiographical narrative.

\section{Refugees and the war}

The First World War was the major transformative event of early twentieth-century Europe. Although initially expected to be one more regional war, international power relations, the nexus of alliances, economic and imperial antagonisms and the rise of nationalism had actually set up the scene for a world war. The experience of the people that lived through it was both unprecedented and devastating: new weapons inflicted losses and casualties on an unprecedented scale and propaganda made the war a cause not only for military forces but for societies as a whole. Most importantly, identities were transformed: participation in the conflict, either on the battlefield or behind the lines, made national identities more conflictual and intolerant. If multiethnic European empires enabled the emergence of fluid, multileveled identities, this was no longer the case in the new context of nation-states. On the one hand, fluid identities were not tolerated and were, instead, inscribed into the national identity that seemed most similar. Multiethnicity, on the other hand, was not part of the postwar regime. Groups that were not part of the dominant nation group were to be controlled through a complex legal nexus, resulting in practices of assimilation, exclusion and minoritisation.

As a result, a widespread refugee movement took place in Europe in the period around the war, either out of fear of foreign invasion or because of the state violence inflicted on refugees as part of the process of their national alienation. Belgians fled to France, Holland and the UK in 1914 and 1915; fearful after Serbia's defeat at the hands of the Austrians, Serbs fled to Albania, Corfu, Corsica and Tunisia. In the Russian empire non-Russian minorities were deported to the western borders while Whites fled to central Europe, the Balkans and Africa after the victory of the Bolsheviks. Finally, Armenians who survived the ethnic cleansing were scattered in the Middle East and the Russian 
empire, only to later migrate anew to western Europe and North America. ${ }^{3}$ In total, the number of displaced population was tremendous: while no accurate figure can be established, data collected from countries all over Europe suggests there were 10 to 14 million displaced civilians during the Great War. Russia alone saw the displacement of about seven million people due to the war, revolution and civil war. Proportionately, about one in ten people in Russia became refugees. ${ }^{4}$ It goes without saying that changes in people's everyday life were beyond imagination. To give an example, the population of the small Serbian town of Prizren swelled from 20,000 to 150,000 in a matter of days in 1915 because of Austro-Hungarian aggression against Serbian civilians. ${ }^{5}$

The situation in the Balkans was even more complex. The rise of nationalisms and national antagonisms in the region resulted in extended population movements in the late nineteenth century, which culminated in the Balkan Wars. Thousands of Muslims fled the Balkans towards Asia Minor and Crete following the Russian-Ottoman wars, while antagonisms between different Balkan nationalisms resulted in widespread turmoil in the region, acerbated by the fact that irregulars participated in these wars. From 1878 to 1913 about 1.7 to 2 million Muslims were displaced from the Balkans to Asia Minor and Eastern Thrace. ${ }^{6}$ The toll was similarly high for other Balkan nationalities. In summer 1906 alone, 20,000 Greeks fled Anchialos (now Pomorie in Bulgaria) due to the extensive pogroms against them. The situation of compulsory population movements only became worse during the Balkan Wars. According to a Carnegie Commission report, some 156,000 people took refuge in Greece and 104,000 in Bulgaria while more than 200,000 Turks fled to Anatolia. ${ }^{7}$ It would be legitimate to claim that the war period for the Balkans was not limited to the conventional period of 1914 to 1918, but extended over a decade, starting from the Balkan Wars and ending with the Lausanne Treaty.

Given this situation, the 1.2 million Asia Minor Greeks and 500,000 Muslims were expatriated from their homelands to Greece and Turkey, respectively, under the Lausanne Treaty are, accordingly, part of a much broader event: that of the population engineering in Europe between the wars, with the emergence of the nation-state as the prevailing form of political organisation. Refugees during this period, though, have been rather overlooked by historians, partially because the latter's interest was focused on the drama played out on the battlefields and partially because the former were perceived as transitionary. The most important issue for the nation-states was political, social and economic reconstruction. Nevertheless, the refugees were not a marginal by-product of the war. Their presence in their new homelands in the interwar period had set into motion changes that structurally affected societies. They were a part of the transformative process that took place during the war and, therefore, they should have central a central role in the historiographical configuration of the war.

In what follows, we will attempt an overview of the way the refugee problem as part of the First World War is configured as an event in Greek historiography. It is beyond the scope of this article to attempt a detailed description of all the relevant works, though. Scholars have already engaged in such a task, especially since the $1980 \mathrm{~s}^{8}$ Our intention is to elaborate on existing historiographies so as to understand the way topics of interest and historiographical questions changed throughout the century, resulting in different historiographical configurations concerning refugees. Schematically, we can discern four main phases (with the respective questions): ${ }^{9}$ The first phase covers 
the historiographical production during the First World War and, throughout the interwar period. The main issues addressed in this period were the attribution of responsibility for the defeat and the social, economic and political management of the "refugee issue". Following a parallel path of dealing with the past, novels elaborated on the experience of the war and its consequences. The second phase covers the historiographical production after the Second World War, especially that of the 1950s and 1960s, when the refugees' narrative had not yet been included in the mainstream historiographical narrative. In this phase, the academic historiographical production began to become interested in research regarding the war decade, on the one hand. However, on the other, the historiographical field of Asia Minor Catastrophe studies began to take shape beyond the academy. The third phase began in the 1970s, when historiographical production became interested, among others, in the subject of refugees. During this period the historiographical field seemed to split and develop along two parallel paths: the first, in which the refugee associations have played the leading role, is connected to a politicised and ethical approach of memory, while the second, cultivated mainly within the academy, is aligned to the broader theoretical problematisations and turns of historiography.

\section{Historiographical configuration in context: the Asia Minor Catastrophe, the end of the "Great Idea" and the "war decade"}

The signing of the Treaty of Sèvres meant the beginning of a new war cycle for Greece and the Ottoman empire - a war that ended with the foundation of the Turkish state and the mutual compulsory population exchange between Greece and Turkey, under the terms of the Lausanne Treaty. Greeks experienced the defeat of the Asia Minor campaign as a major trauma: not only in terms of the huge economic burden caused by the war or the loss of lives. More than these, the defeat marked the de facto abandonment of the Megali Idea ("Great Idea") - the ideological and political project that was first formulated in 1844 and had shaped the way the nation was conceptualised, including national time and space, even when it was not dominant. ${ }^{10}$ What was the Great Idea? Namely, it was verbalisation of the idea that Hellenism was a much wider notion, one that could not be limited to the citizens of the Greek kingdom and that, therefore, co-ethnics lived beyond the state's territory, mostly in the Ottoman empire. Besides the different interpretations it acquired during the nineteenth century and the differences in the political projects undertaken in its name, the Great Idea was at the core of the nation's historical consciousness: the two main pillars of the teleological conceptualisation of historical time during the nineteenth century entailed the spatial unification of Hellenism and its temporal unification, with the reconstitution of the continuity disrupted by the Fall of Constantinople in 1453.

During the Balkan Wars and First World War, the materialisation of the Great Idea seemed more possible than ever. Greece had almost doubled its territory, gaining access to both sides of the Aegean. It was the conviction that the involvement in the World War and the undertaking of the Asia Minor campaign were the last steps needed to fulfil the dream of a Greece of the "two continents and five seas". This justified, in the eyes of public opinion and politicians, the sacrifices that these wars (and others, such as the participation in the Allied intervention in Ukraine) entailed. ${ }^{11}$ Never- 
theless, the defeat in Asia Minor brought such dreams to a violent end. The Great Idea, or at least the prospect that it could ever be materialised, was dead in effect. It was followed by an ideological vacuum and the need to explore new prospects for the nation. The situation bore the characteristics of a national crisis: in the absence of the Great Idea, a series of choices, especially from 1880 to 1922, when a rather more assertive foreign policy was adopted, following the annexation of Thessaly in 1881 and the emergence of Balkan nationalisms, were no longer meaningful. Greece would not expand to the limits of Hellenism. Rather, the situation was reversed: the new quest was for Greece to absorb Hellenism. ${ }^{12}$

It was within this framework of emptiness and exploration for new meanings that the Great War was gradually constructed as an historiographical event. Its negotiation was difficult from the beginning. The situation in Greece was already tense before its defeat in the war. Over the question whether Greece would participate in the Great War, a rigid division between King Constantine and Prime Minister Eleftherios Venizelos gave voice to the culminating tension between Old Greece and the New Lands. ${ }^{13}$ It was a situation with devastating consequences, where half the nation refused to go to war for the other half - a situation that demonstrated that national homogeneity was still a process in the making. The National Schism, although officially brought to an end through the intervention of Britain and France by 1917, continued well into the years that followed, defined the outcome of the 1920 elections and gave the tone to the interwar political constellation. Besides its political aspects, the schism codified and included social elements as well, such as labour and agriculture issues and the refugee question, setting the interwar political scene. ${ }^{14}$

The reality of the schism defined the historiographical construction of the Great War throughout the interwar period and well into the initial post-Second World War decades. The tension between the two parts often resulted in divided memory and silences, at least at the public sphere. Dimitris

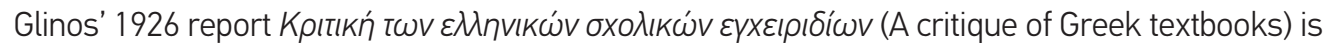
indicative of this tension. It underlined that the complete silence in the textbooks about the Great War and their scarce references to the Balkan Wars were not to be understood only as a result of the weariness following on from the wars that had lasted for over a decade, but also as a result of the schism and the special conditions it gave rise to in Greek society. ${ }^{15}$

The historiographical treatment of the First World War as an episode of the war decade rather than as a separate episode of the national biography attempted to overcome this difficulty. This option eased the importance of the schism as an autonomous historical event - and therefore its visibility. The same choice defined the framework for the central memorial policy followed by the state in the interwar period. The issue became urgent in the early 1920s, when the Allies decided to establish military cemeteries on battlefield sites in Greek territory (in Doiran in Kilkis and Mudros on Lesvos, for example). Greece then needed to decide how it would handle the issue and, more broadly, its own memory of the war. Thus, almost immediately after the Asia Minor Catastrophe, the state, in cooperation with the army, decided to undertake a centrally organised political monument-building programme that would not address the Great War as such, but the entire war decade of 1912 to 1922. ${ }^{16}$ Therefore, the Great War was contextualised in the temporal framework of the war decade and officially considered as an episode in the national biography that led to the emergence of the modern Greek state (with all the losses and ambiguities that this modernity entailed). 


\section{Interwar configurations of the war decade}

The first historiographical constructions of the war published during the interwar period reflected the burden of the defeat and the division of the society due to the schism, which was still vivid. The attempts to deal with the recent past of the war and the attempts to make sense of it followed three strands, one of which was followed by veterans, some of whom had fought for a decade, from the Balkan Wars until 1922. Another strand was pursued by politicians; contrary to the veterans, they were more engaged with solving the pressing problems of the present, especially as far as returning to normalcy after the war and the need to accommodate the refugees was concerned. The third strand was the literature that dealt with the grassroots experience of soldiers and citizens after the war.

The postwar memoirs of veterans engaged in the first attempt to construct the Great War as an event. But why did they write? An important motive for engaging with the past, if not out of sole academic curiosity, is to make sense of it, so as to be able to navigate in the present. This also applied to the veterans. A generation that had grown up in war conditions, its members had dedicated most of their youth to fighting for the expansion and, eventually, the consolidation of Greece. After the Asia Minor defeat, they were confronted with the disillusionment caused by the Great Idea, the disappointment that their sacrifices had been in vein. They were not prepared to abandon decision-making to politicians, though, and they claimed an active role in the postwar political scene. Being unavoidably heavily involved in the schism, in their memoirs they address the question of accountability for the defeat. Depending on whether they were written by supporters of King Constantine or Prime Minister Venizelos, the interpretation of the series of events that led to the defeat is different. According to those veterans that supported the king, responsibility for the defeat was shared both by the prime minister and the veterans who supported him and who conducted the Asia Minor campaign. On the other hand, essays by Venizelist supporters provide a different aspect of the story, holding the king accountable for a number of wrong decisions. In this sense, and given the time in which most of the memoirs were written, they provide not only a narrative of the political and war events, but serve as an opening through which the deep division of the schism can be traced. Despite their differences, however, these memoirs deal with the war decade as an entity, a choice which is more or less aligned with the way the veterans experienced it, their approach focusing mainly on political and strategic decisions.

Among the most characteristic memoirs on the pro-Constantine side is, for example, that by Xenofontas Stratigos. A senior army officer and a minister in the Gounaris-Protopapadakis governments, for which he was sentenced to life during the "trial of the six", Stratigos published the book

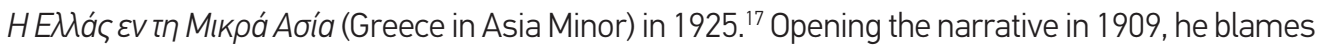
the defeat on Venizelos, not only because of his political decisions regarding the Asia Minor campaign, but also because of his political decisions during the schism. A similar argument is followed

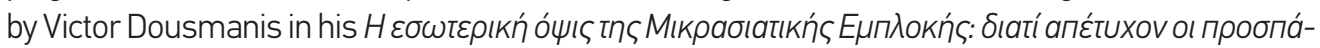

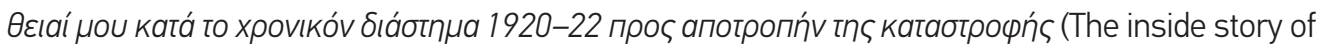
the Asia Minor imbroglio: why my attempts in 1920-1922 to avoid the catastrophe failed), which was published in 1928. Having fought in all the conflicts since the Balkan Wars as a high-ranking officer, Dousmanis attempts to provide a balanced analysis of the errors and faults that led to the 
defeat. Nevertheless, even in the introduction, he clearly states that Venizelos and Venizelist soldiers were mainly responsible for leading the army towards catastrophe.

On the other side of the spectrum were the narratives by Venizelist veterans. They also focused on the whole decade, though occasionally from the Goudi coup, after which Venizelos had a leading role in Greek politics, and highlighted strategic and political decisions. But the blame for the defeat

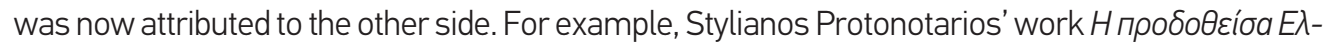

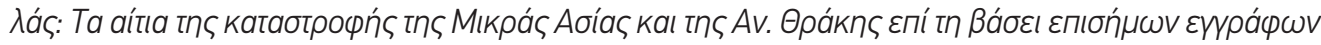

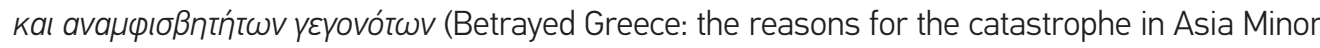
and Eastern Thrace based on official documents and undeniable facts) was published in 1922, with an introduction by Nikolaos Plastiras. Protonotarios held the Gounaris-Protopapadakis governments accountable for the defeat and, in doing so, provides ideological support for the Plastiras-

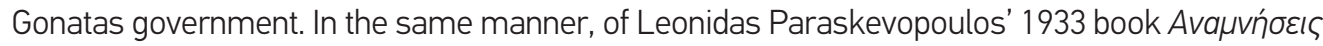
1896-1920 (Memoirs, 1896-1920) weaved the narrative from the Macedonian question and the Ethniki Etaireia up to the Mudros Armistice, blaming King Constantine for a series of unfortunate

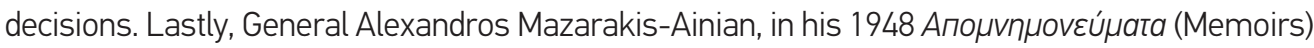

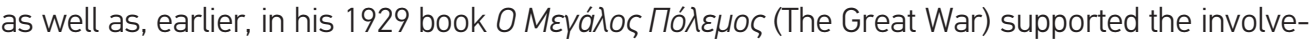
ment of Greece in the war, criticising nevertheless a series of decisions taken during the Asia Minor campaign, especially after 1920, when the anti-Venizelists came to power. In the same vein, although not written by a combatant but by a journalist that was in Venizelos' close circle, is Georgios Ventiris' 1931 book H EMás tou 1910-1920 (Greece, 1910-1920). Ventiris bases his analysis on essentialising discord as an endemic characteristic of the Greek nation that caused a series of catastrophes. Nevertheless, writing about events that he had participated in or knew from his close association with Venizelos and his environment, he provided a detailed account of the social, political and war situation in Greece during the decade, focusing on the schism.

Attributing accountability for the defeat and achieving "catharsis" after the trauma of the end of the Great Idea was not the only issue that interwar historiographical production had to address. The pressing problems of the present, namely a destroyed economy combined with the massive presence of refugees who were now considered permanent, shaped a volatile situation in need of immediate attention. A corpus of scholarship regarding the refugee issue, addressing the social, political and economic aspects of the problem, was produced during this period. In this context, the past was examined not for its own sake, but to provide argumentation for the present. The essays were written as part of the attempt to conceptualise the refugee issue as a humanitarian crisis - a concept that due to and after the Great War had replaced that of philanthropy. ${ }^{18}$ Therefore, they dealt with the issue of refugees from an economic, political and social perspective, aiming to overcome the crisis and include the refugees in Greek society. ${ }^{19}$ The authors were mostly politicians or held important positions in the state mechanism. Although not necessarily of Asia Minor origin, they worked towards the solving of the economic, social and political aspects of the issue.

For example, in 1923, Anastasios Bakalbasis, an MP and minister in many Liberal Party govern-

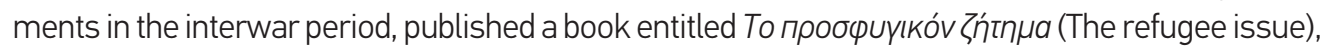
which dealt with the refugee issue from the beginning of the Great War to the Asia Minor Catastrophe, mostly addressing the need and the ways in which the refugees could be settled and includ- 
ed in Greek society and the economy. Along the same lines in 1930, Athanasios Petsalis-Diomidis

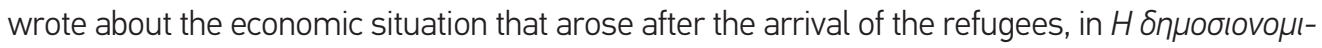

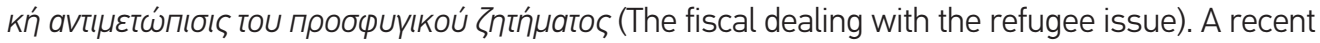
law graduate, he worked in the research department of the National Bank of Greece and was interested in the ways the economy would be affected by absorbing such a large refugee population and in possible avenues to meeting the fiscal demands required by their settlement. Emmanouil Tsouderos, who systematically shaped the framework for refugee compensation and published a book on this theme in 1927, was the director of the central Bank of Greece, while Ciriaque Georges Tenekides, who wrote on the compulsory exchange of populations, was Venizelos' legal advisor at Lausanne..$^{20}$ Athanasios Protonotarios, who supervised the committee for the exchange of

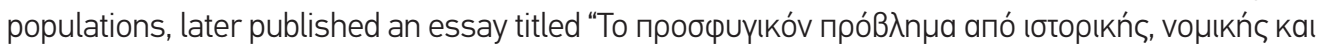
крatıkń anó $\psi \varepsilon \omega \varsigma "$ (The refugee problem from historical, legal and state aspects). Stelios Seferiadis, who in 1929 published an essay on the population exchange, was a law professor at the University of Athens. ${ }^{21}$

The Marxist trajectory in the historiographical production during the interwar period deserves special mention. Marxism in Greece appeared in the public scene in the late nineteenth century, although critical social thinking reached wider audiences only after the First World War, when social

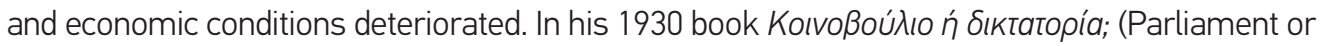
dictatorship?), Serafim Maximos, an interwar communist intellectual, provided a different narrative of the events of the war decade. He brought to the fore the notion of class in the shaping of politics, especially after 1909, and the role of the army, which he regarded as part of the political dynamics of the period. He argued that although the army was more or less national at the time of the Balkan Wars, the popular-liberal alliance that was at its base was broken during the Great War. According to him, the main reason for the defeat in Asia Minor was the clash between social classes, the army and the decision-making centres. ${ }^{22}$

These two strands of dealing with the war decade, however important both for its construction as a historiographical event and for solving issues of the present, did not give voice to the grassroots experience of war and refugeehood. Working through such experiences was considered a luxury, given the imperative need to find a way to move on. Nevertheless, the experience was so traumatic that it could not be silenced - nor could it yet be faced from a distanced perspective. Literature, in Greece as in the rest of Europe, and art filled the gap in this case, articulating the grassroots experience through the emergence of modernism. Of course, the topic of refugees and their presence in the Greek state had preoccupied literature even before the evacuation of Anatolia - the movement of populations from and towards the Ottoman empire and other Balkan nation-states had been a constant feature at least since the Balkan Wars. From 1922, though, and after both the natives and refugees realised that it was not a new "refugee crisis" but a permanent situation that had to be lived with, literary output became denser. The same holds true for grassroots literature on the experience of war. ${ }^{23}$ Initially such stories were published in the press, until the late 1920 s and early 1930s, when the relevant literary production became more extensive and appeared as books. The literature written by the refugees had the characteristics of the literature of exile and expressed all the emotions of loss, alienation and nostalgia for a homeland whose loss is perceived, in this case, as permanent. ${ }^{24}$ In this sense this literature resembled the exile literature written in Europe during 
the interwar period and constitutes a distinct literary genre that gradually integrates the experience of the exiled into the national narrative. ${ }^{25}$ Greekness and the social contract, the aestheticisation of space, the handling of difficult memories, and the limits and practices of inclusion and exclusion all become aspects of a discussion that constitutes the modern condition and, at the same time, seeks the expressive means and intellectual tools for its management. Refugee literature, as was the case with the literature of the Great War, both during the interwar period and during its second phase, in the 1960s, functioned in between fiction and testimony. Autobiographical novels of the

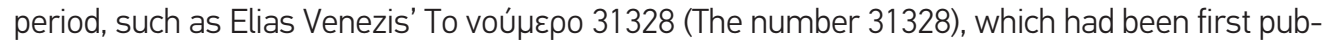
lished in 1924 (initially in the Kambana newspaper on Lesvos and later as a book in 1931), Stratis

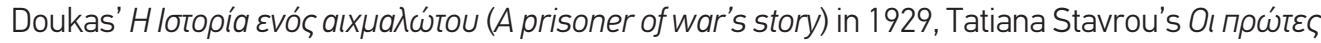

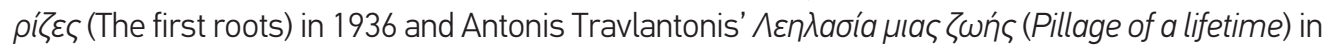
1936 are attempts to understand the new condition and its limits, through narrating the experience of war and refugeehood, before such novels obtained national characteristics during the 1960s. In such novels space is a central element of the textual construction, the canvas on which not only the action is placed, but through which the identity of the refugees is implied and the mental geographies of belonging are elaborated. In other words, literature represented and contextualised space in a process of making history through cultural practices.

\section{Postwar historiographical constructions}

The historiographical construction of the war decade that includes the Great War changed drastically after the end of the civil war (1949). Firstly and most importantly, during this period refugees and Asia Minor studies gradually become crystallised into a distinct field in Greek historiography. Two major elements helped differentiate this period from the previous one: on the one hand, the experience of the 1940s, which had shaped new divisions in society that were based on the dichotomy between communism and national-mindedness, resulting in the fading of the old divisions between natives and refugees (which, nevertheless, sometimes had found new ways of expression in the new context). ${ }^{26}$ On the other hand, the old generation was gradually being replaced by a new one which did not have first-hand experience of the war decade (or had experienced it in their early childhood), resulting in the gradual replacement of experienced memory from post-memory and eventually cultural memory. ${ }^{27}$ Furthermore, experiences connected to the Second World War and, most importantly, the Holocaust raised awareness of the importance of oral testimony for grasping a relatively fuller representation of the past.

Historiographical constructions of the war decade during this period were elaborated both within and outside the academy. Scholarly interest in Asia Minor refugees increased after the 1955 September violent events in Istanbul targeting the Greeks, which was conceptualised as a continuation of the events of 1922. Asia Minor refugees returned once again to the centre of public attention. Indicative of such interest are the essays of Maximos Maravelkis and Apostolos Bakalopoulos, $A \iota$

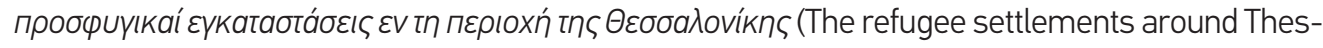
saloniki) (1955) and Dimiri Pentzopoulos, The Balkan exchange of minorities and its impact upon Greece (1962). These were the first scholarly historiographical approaches to the subject, that, nev- 
ertheless, remained within the dominant narrative of the everlasting clash between Greece and Turkey, according to which the Ottoman period was a dark interlude in the nation's destiny. Special

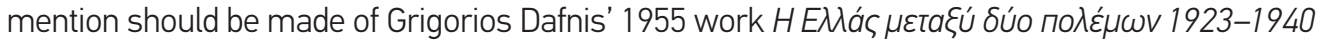
(Greece between two wars, 1923-1940), detached the Asia Minor Catastrophe from the preceding war decade, contextualising it as the first episode of the fragile interwar period and road towards the 1936 dictatorship.

Regarding the commemoration of the Asia Minor Catastrophe, though, the state was reluctant to undertake the initiative of bringing the memory of the refugees into the public sphere because, among other reasons, of its political choice to normalise relations with Turkey, which had come to be considered an ally in the containment of the "communist threat". Besides, refugee memory was not yet part of the national memory and, therefore, the initiative for dealing with it could be left without major problems to the left. Given the restrictions and the censorship of the anticommunist regime, however, the left did not have much space to negotiate this memory. ${ }^{28}$ The new narrative was disseminated mainly through cultural production beyond the academy - given the strict anticommunism of the period that characterised much of academic activity. Novels written on the occasion of this commemoration introduced the use of memory and orality as crucial in understanding the authenticity of the experience. Novels that were published in this period - such as Dido

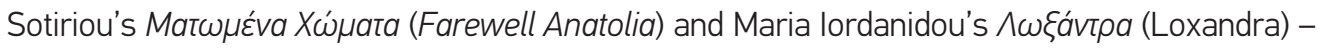
brought memory and orality to the fore, claiming that both were crucial for understanding the experience of the Asia Minor Catastrophe. The novels underlined the role and the responsibilities of the Greek state in the context of the power games and imperialist politics of the period. Moreover, such novels clearly depicted everyday life in the Greek communities of Asia Minor and, as a result, Asia Minor cultural identity became more clear, vivid and distinct. This identity, which also echoed the refugee identity, was proposed as the positive counterpart of the rigid identity of the natives and gradually shaped the image of the refugee that has since prevailed in cultural memory - an image that lies between experience and nostalgia and refers to the open possibilities of a world that has passed. Such novels gradually shaped a critical discourse that challenged the dominant narrative about the Asia Minor Catastrophe as well as approaching it through the Venizelist and anti-Venizelist dichotomy. It is important to state that, although the division between Venizelism and anti-Venizelism was not as rigid in the social and political sphere, it often found its way into the cultural sphere, which kept these dichotomies alive. For example, a "history war" broke out in the mainstream press regarding whether and in what context Venizelos and his legacy should be included in 50th commemoration of the Balkan Wars. It was a clear indication that Venizelos, who would later become the central figure through which the war decade was approached, had not yet been incorporated by the postwar anticommunist state. ${ }^{29}$

Within the same interpretative framework that criticised and challenged the dominant national narrative were some historiographical essays written by historians affiliated to the left. Nikos Psyroukis' book H Mıкрaбıatıkń Kataбtpoøń (The Asia Minor catastrophe), which is based on his doctoral thesis submitted to the University of Prague in 1956, contextualises the Asia Minor campaign in the context of the international antagonisms of the period and criticises the way national historiography did not take into account class and social aspects relating to the locals and the refugees. His work is perhaps the most characteristic of a series of essays - that mostly appeared in 
newspapers - which approached the catastrophe in a similar manner, bringing the experience of war and refugeehood beyond the interpretations imposed by national discourses by attempting to trace its social and political contexts. In such approaches, the existing dichotomy between natives and refugees is transformed through a series of interpretational approaches that acknowledges that Greek interwar society was multifaceted and the way that its divisions transcended categories such as natives and refugees.

Of special interest regarding the way it stimulated historical research is the establishment of the Centre of Asia Minor Studies in the late 1940s and early 1950s. The origins of the centre go back to the interwar years, when Melpo Logotheti-Merlier, in collaboration with the University of Paris, undertook the task of collecting and recording the music tradition of Greek refugees. After many adventures, the centre was finally established as such in 1948, part of the state's modernising process that resulted in the setting up of a number of similar foundations in the 1950s. Through semi-structured interviews, researchers at the centre collected the testimonies of refugees who arrived in Greece from Asia Minor in the 1910s and 1920s, recreating the story of the initial uprooting and later resettlement. The centre's grassroots approach and the way it valued orality provided an alternative approach to the past, and laid the basis for the emergence of refugee studies as a distinct research field. Refugees gradually became a distinct collective subject with cultural characteristics, no longer regarded as alien, but as a part of Hellenism that could not be allowed to fall into oblivion. ${ }^{30}$

\section{Creating a space of their own: refugee narratives of belonging}

From the outline above of the dominant historiographical narratives concerning the Great War, it is obvious that the voice of the affected population was missing, at least until the 1960s and the commemoration of the 40th anniversary of the Asia Minor Catastrophe. So how did voices emerge from below? How was the space for the inclusion of refugees into the national historical narrative created? This was the achievement mainly of refugees themselves, or better, of a group of them that functioned as organic intellectuals. ${ }^{31}$ Historiography played its role here, bridging the gap between the host community and the refugees by creating the space they needed to become national subjects. The agents that took it on themselves to write history were intellectuals of Asia Minor origin who had already established a standing in Greece before the uprooting. They were mostly members of the higher echelons of Greek society: MPs, university professors, high-ranking veterans or clergy and they mediated the memory of Greek Asia Minor communities so as to include it in the national narrative and imaginary.

Their task was twofold: to create space in the national narrative for the newcomers and to reinvent the refugees as a group that, on the one hand, was part of the nation but on the other was bound by a distinct cultural identity and memory. To pursue the first task of creating space in the narrative, historians and intellectuals engaged heavily with the past in articles in specialist journals, which enabled them to include the refugees' Asia Minor past into the national canon. In other words, they invented a history for their homelands that could be adapted to the demographic circumstances of 
the turbulent twentieth century. In this effort, historians focused on two main topics. They reimagined the Asia Minor space as historical regions that were part of the nation's imaginary. For this, they built on existing historical geographies, such as that by Pantelis Kontogiannis. ${ }^{32}$ After space, they appropriated time. They wrote extensively on the cultural practices and the past of Asia Minor communities, in a way that their history (cultural, monumental, ecclesiastical and political) gained a national contextualisation, therefore creating the prerequisites for their national inclusion - a pattern similar to the history of the White Russian diaspora in Europe. ${ }^{33}$ Language, everyday life and oral tradition all became part of a newly formed "refugee culture", that gradually joined the other regional cultures that constitute "Greekness". The most interesting part of this process, though, was that Asia Minor regions were nationalised by historiography a priori created as an idealised lost homeland - an object of loss that can be mourned and longed. Nostalgia, thereby, came into its own as an historical interpretation of the long-term effects of the upheaval of the First World War and its aftermath. The second task, that of the nationalisation of the refugees and their transformation into communities of memory, whose narratives could fit into the national one, was pursued through a series of historical and cultural practices (journal contributions, grassroots work, engagement of a wide circle of intellectuals and clergy in the tasks of community formation, etc).

The outcome of this process was that, gradually, the diverse, dislocated population from Asia Minor that in the 1910s and 1920s still carried the fluidity and multiplicity of imperial and local identities of belonging and had not yet developed a national identity, became nationalised through the appropriation of a refugee identity which, in turn, was constructed not as an alternative, but as complimentary to the national one. In other words, forms of the national narratives were used as a starting point for the adaptation, on which the refugee past was created. In the long run, even a three-part narrative form comprising a golden past, a dark interlude and a rebirth evolved. The refugees themselves told a heroic story. To them, the golden past was the image of the lost homelands, the interlude the experience of expatriation and the hardships of the first years as refugees, and the triumphal outcome the way they blossomed within and renewed Greek society over the decades.

\section{The last quarter of the twentieth century}

In the 1980s the third generation of refugees took ownership of the public discourse on refugee memory. The notion of trauma gradually became mainstream in the discourse on refugees and a central concept around which their cultural identity and the narrative of their past was shaped. In a manner that resembles what Svetlana Boym terms restorative nostalgia, memory became politicised and claimed its space and visibility in the national narrative. ${ }^{34}$ The story of the past became a memory that sought revenge, tied to the suffering of the past, looking for vindication instead of understanding and seeking to keep the wound open. The subtext of this narrative is political: it argues that the state, by following a foreign policy agenda that aims to maintain amicable relations with Turkey, has downgraded the memory of expatriation and has not done justice to the suffering of the refugees. ${ }^{35}$ Such an approach, while it reflects the way refugeehood has been established at the centre of the cultural identity of the third generation after the Asia Minor Catastrophe and is, therefore, useful in understanding the path from marginalisation to 
domination, at the same time fails to take into account the historical context within which the Asia Minor Catastrophe emerged both as a historical event and as a lieu de mémoire that became a core component of the contemporary national canon. In other words, although it is the inclusion of refugee history in the national narrative that provides the space it needs to emerge, at the same time it overlooks the historicity of its historiographical production, essentialises refugee identity and projects it onto the past.

The shaping of and claims to a refugee memory based on the concept of trauma was new and connected to the broader dissemination of notions of trauma that gradually emerged after the Holocaust. Traumatic approaches to history are in contradiction to the dominant concept of heroism, around which both leftwing and rightwing narratives developed until the 1960s. The same was true for narratives of refugeedom. Such narratives developed around the core argument that, although refugees encountered, in the first years of their arrival, enormous difficulties, they did not only manage to adapt to their new homeland, but they prospered, playing a central role in renewing Greek society and leading its industrial development and modernisation process. ${ }^{36}$ The narrative of trauma moved in a different direction. Trauma became the main argument for claiming a distinct (and recognisable) cultural identity for groups that had known violence in both world wars. Especially after the Greek state's official recognition of the Armenian genocide in 1987, other refugee associations argued that they too were victims of genocide. Refugee memory could no longer be marginalised; instead refugee associations asserted a countermemory that claimed both victimhood and the right to be recognised as victims of similar crimes (Pontian and Asia Minor Greek). ${ }^{37}$ The gradual nationalisation of such a traumatic memory, based on sufferings inflicted by the Turks on Pontian and Asia Minor Greek populations, focused on the relationship between Greeks and Turks and was closely related to the core national narrative. Traumatic motifs quickly became central to public history and popular discourse, particularly when the Yugoslav Wars revived nationalist sentiments in the region. This kind of approach to the refugee problem, which was aligned to traditional historiography but had remained marginal in academic historiography, sought validity abroad, mainly in diaspora associations.

At the same time, after 1974 historians that had been excluded from university posts by the post-civil war state were appointed professors, while historical studies were renewed internationally due to the opening up in different fields. As a result, the historiography of the 1912-1922 period was renewed in this period. ${ }^{38}$ The gradual turn towards social history was already evident from mid-1970s, but it was mainly in the 1980s that the war decade was approached from perspectives other than war and its consequences ${ }^{39}$ An example of this approach was Angelos Ele-

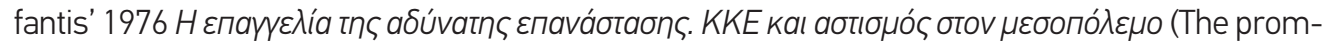
ise of the impossible revolution: the KKE and urbanism in the interwar period), that discusses war and refugeehood only as far as they are related to the shaping of the Communist Party of Greece (KKE). Such essays would multiply in the following decade. They deal mainly with the economic and social history of the interwar. Studies such as that of George Mavrogordatos' 1983 book Stillborn Republic: Social Coalitions and Party Strategies in Greece, 1922-1936, Lila Leontidou's 1989

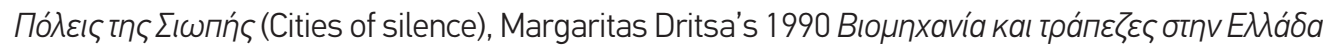

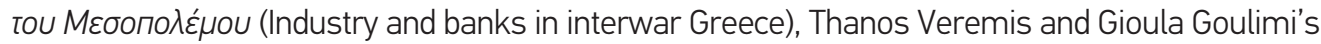

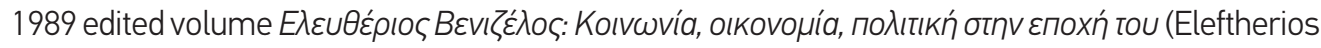


Venizelos: society, economy, politics in his era), which contains chapters on all the aspects of the social, economic and political history of the period, from Venizelos' arrival on mainland Greece to

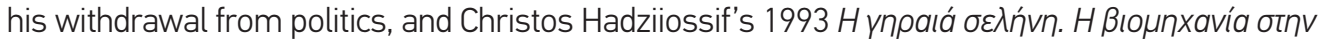
EMnvikń olkovouía, 1830-1940 (The old moon: industry in Greek society, 1830-1949) question the way traditional historiography approached the wars of the 1910s and the accommodation of the refugees as an episode in the national biography, beyond political, social and economic contex-

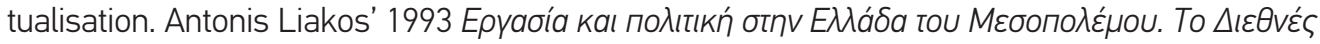

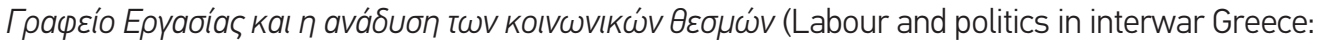
the International Labour Office and the emergence of social institutions) moved the abovementioned problematisation a step further, enrichening the discussion with the need to investigate the multiple aspects of the political, social and economic phenomena of the period, not only within national contexts but mainly in the way they communicate, jointly shape and become entangled with similar processes internationally. At the same time, George Leontaritis' 1990 Greece and the First World War: From Neutrality to Intervention was the first study of the diplomatic and political history of the First World War in Greek historiography, contextualising the Greek experience of the Great War within the international framework.

In the 1990s, when history opened up towards the questions and methodologies of social anthropology and the development of memory studies, new questions and paths were set for the study of the exchange of populations and the refugee issue. The conference " $0 \Xi \varepsilon p ı \zeta \omega \mu$ ó kaı n á $\lambda \lambda n$ пatpí́a" (Expatriation and the other homeland), which was organised by the Moraitis School in Athens in 1997, was a turning point in the renewal of interest in the history of the refugees. The core of the subsequent edited volume demonstrated the clear shift from the defeat of the Greek army in Asia Minor to the issue of refugee accommodation and integration, with essays that investigated aspects of economic, social, residential, cultural and political history of the refugees. Studies of this period shed light on aspects of the refugees' subjectivity, renewing the historiography of the Asia Minor Catastrophe and the refugees. Studies such as Renée Hirschon's on the refugee suburb of Kokkinia in Piraeus in the 1970s are focused on the voice of the refugees and reveal their complex and multifaceted identity.

The turn of the century found academic historiography on the refugees more or less detached from the national discourses and aligned with the new historiographical trends. At the same time, the emergence of memory studies had initiated a process of a joint revisiting of difficult and traumatic pasts by the interested parties, so as to gain insight into what happened and work through the trauma. This was the context in which the historical community undertook the initiative to experiment with organising shared conferences between Greek and Turkish scholars as well as to publish edited volumes with contributions from both sides. ${ }^{40}$ The historiographical production of the twenty-first century is so voluminous that it is beyond the scope of this study to discuss it. Nevertheless, what can be generally stated is that the core trend characterising the majority of these studies is that they do not investigate the war and the population exchange within the framework of national historiographies but within the framework of Ottoman history, its attempts towards modernisation, its gradual nationalisation and the wars that led to its destruction. ${ }^{41}$ Lastly, studies that critically approach discourses on Asia Minor and the Catastrophe appeared in the same period. ${ }^{42}$ 


\section{Conclusion}

This article retraced the various paths that Greek national historiography followed in dealing with the refugees as a special aspect of the war decade of 1912-1922. It detected the different historiographical questions that were raised in response to different historical contexts, and to experiences in need of interpretation and accommodation. Major traumatic experiences of the twentieth century, such as the Holocaust, shed new light in approaching the past: over the decades, questions moved from a historiography of action to a historiography of suffering, and interest shifted towards testimony and the subjective experience of suffering.

But the core of the historiographical configuration of the refugees and the decade as a whole remained more or less dominant, at least in the mainstream narrative. Although population uprooting and forced migration was a widespread practice across Europe and part of social engineering of the time, when it acquired meaning within national narratives, as in the case of Greek historiography, it was reinterpreted as exceptional and traumatic. It then shaped not only cultural but national identities as well. The contextualisation of the expulsion of the Greek population from Asia Minor within the narrative of the Asia Minor Catastrophe points to the direction of nationalising (and thus making unique) the experience of the Great War. The trauma was balanced, though, by underlining the effectiveness of the nation-state that emerged after the war. It was a modern state, which had given up its imperial dreams of reconstituting the Byzantine empire, becoming small but effective, to an extent that it managed to accommodate the refugees and accomplish economic growth. The new narrative was a top-down one that acknowledged the state as the actor, while at the same time relegating or withholding multiple, fluid and often contentious identities and ideologies that prevailed before and during the war (for example, political ideologies, old Greece and the New Lands, locals and refugees, ethnic minorities, etc).

Although the historiographical constructions of the First World War and the refugees gradually become more permeable to historiographical turns and trends that transcend the limits of national narratives, they are still very much embedded in national narratives, as part of the biographies of nation-states. Furthermore, they remain strong in public and lay history. Nevertheless, such approaches hinder the understanding of the transformative dynamics of the interwar period, such as the way that the construction of refugees as a distinct social category set in motion structural changes in societies or that the cultural identities that refugees formed affected the national identities, forming new lieux de mémoire. Therefore, it seems that there is a need to relativise the role of national ideology regarding the research and study of the Great War. In other words, if the approaches so far emphasise the importance of the diffusion of nationalism as the main cause of the war, it might be useful to consider that to a great extent nations were forged during (and as a result) of the war. The most important contribution of nationalism should not be sought in the origins of the war, but in the configuration of the postwar world and in the shaping of the ways the past was conceptualised and the frames in which it is conceived. 


\section{NOTES}

1 See, for example, Shanti Sumartojo and Ben Wellings, eds., Nation, memory and the Great War commemoration: mobilizing the past in Europe, Australia and New Zealand (Oxford: Peter Lang, 2014).

2 The refugee waves from the Ottoman empire towards Greece were so intense at that time that an agreement for mutual population exchange was prepared in 1914. It did not materialise because of the outbreak of the world war. See Yiannis Mourelos, "The 1914 persecutions and the first attempt at an exchange of minorities between Greece and Turkey," Balkan Studies 26/2 (1985): 389-413

3 Peter Gatrell, The making of the modern refugee (Oxford: Oxford University Press, 2013).

4 Peter Gatrell, "Refugees and forced migrants during the First World War," Immigrants and Minorities 26/1-2 (2008): 82-10.

5 Peter Gatrell, "Refugees," in 1914-1918 online: international encyclopedia of the First World War, ed. Ute Daniel, Peter Gatrell, Oliver Janz, Heather Jones, Jennifer Keene, Alan Kramer and Bill Nasson, accessed 17 Jan. 2017, http://encyclopedia.1914-1918-online.net/article/refugees.

6 Mark Mazower, The Balkans (New York: Modern Library, 2000), 11.

$7 \quad$ Alan Kramer, Dynamic of destruction (Oxford: Oxford University Press, 2007), 139.

8 Among existing bibliographies on the Asia Minor Catastrophe and the refugees that map the historio-

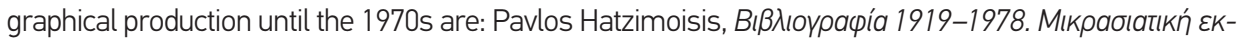

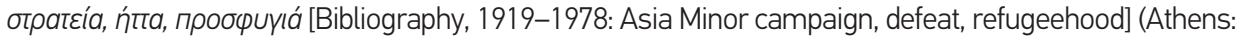

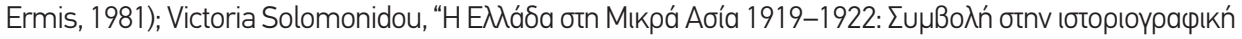

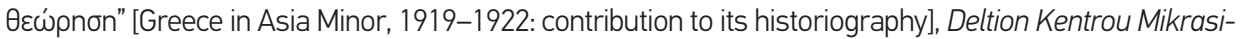

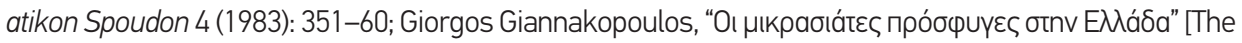
Asia Minor refugees in Greece], Deltion Kentrou Mikrasiatikon Spoudon 9 (1992): 283-91.

9 These phases are more or less aligned to those followed by most national historiographies regarding the configuration of the First World War. See Jay Winter and Antoine Prost, The Great War in history. debates and controversies, 1914 to the present (Cambridge: Cambridge University Press, 2005), 197.

10 On the Great Idea and the way it defined the political and ideological discourse in 19th- and early

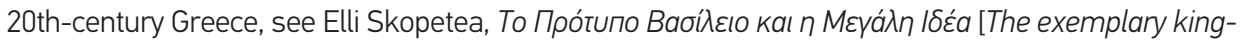
dom and the Great Idea] (Athens: Polytypo, 1988).

11 During the war, though, the perception was different and the Sèvres Treaty was perceived to be the last episode in a genealogy of wars that started with the revolution of 1821 and would end with the restoration of the glory of the Byzantine empire through the modern Greek state. The prospect of this expectation had set the tone in the preparations for the commemoration of the centenary of the Greek

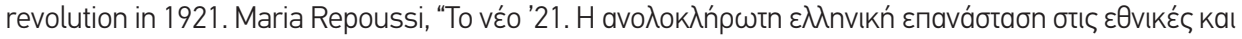

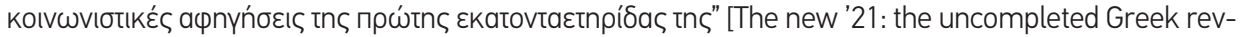

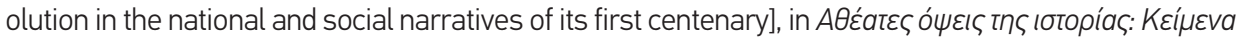

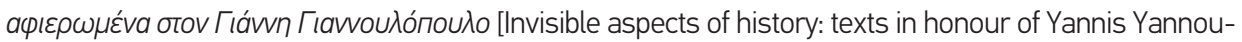
lopoulos], ed. Despina Papadimitriou and Seraphim Seferiadis (Athens: Asini, 2012), 161-80.

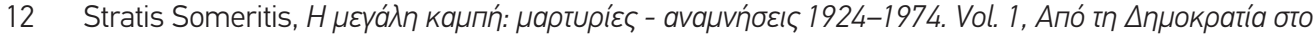

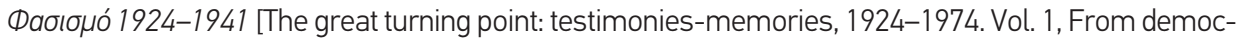
racy to fascism, 1924-1941] (Athens: Olkos, 1975), 32.

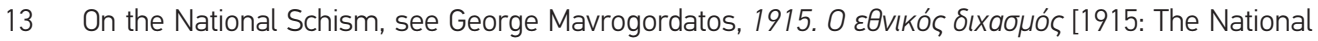
Schism] (Athens: Patakis, 2015). 
14 Augusta Dimou, Entangled paths toward modernity: contextualising socialism and nationalism in the Balkans (Budapest: Central European University Press, 2009), 360ff.

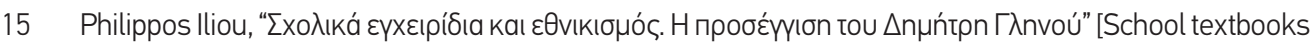

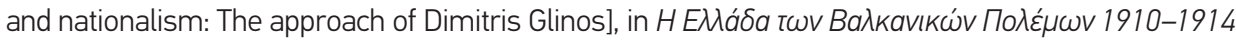
[Greece of the Balkan Wars, 1910-1914], ed. Lydia Tricha (Athens: ELIA, 1993), 274-275.

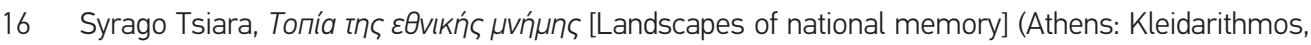
2004), esp. 55-62.

17 The "trial of the six" was the trial for treason in Athens in late 1922 of eight anti-Venizelist officials who were held responsible for the Asia Minor Catastrophe. A Venizelist government was in power, following a coup that had overthrown the government in response to the military defeat on the battlefields of Asia Minor. Six of the officials were sentenced to death, and executed the same day, and two to life imprisonment.

18 See Bruno Cabanes, The Great War and the origins of humanitarianism, 1918-1924 (Cambridge: Cambridge University Press, 2014). Nevertheless, the concept that state intervention was needed to stop massacres and protect the right to life had begun to develop earlier, during the 19th century, esp. in Britain and France. See David Rodogno, Against massacre: humanitarian interventions in the Ottoman empire, 1815-1914 (Princeton: Princeton University Press, 2012) and Caroline Shaw, Britannia's embrace: modern humanitarianism and the imperial origins of refugee relief (Oxford: Oxford University Press, 2015).

19 Details on the books mentioned here can be found in Onur Yildirim, "The 1923 Population Exchange, Refugee and National Historiographies in Greece and Turkey," East European Quarterly 40/1 (2006): 49-51.

20 C. G. Ténékidès, "Le statut des minorités et l'échange obligatoire des populations greco-turques," Revue générale de Droit international public 31 (1924): 72-88.

21 Stelio Séfériadès, "L'échange des populations," Recueil des cours de l'Académie de droit international de La Haye 24 (1928): 307-440.

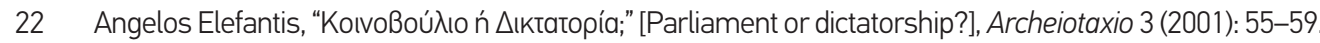

23 On the relation between literature and Asia Minor refugees, see Thomas Doulis, Disaster and fiction: modern Greek fiction and the Asia Minor disaster of 1922 (Berkeley: University of California Press, 1977);

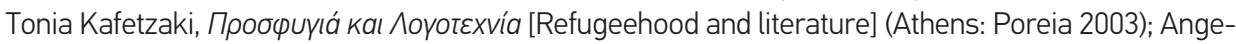

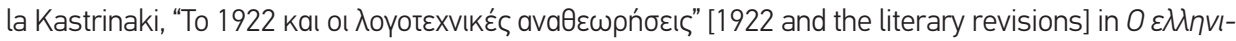

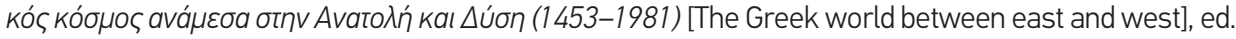
Asterios Asteriou, Konstantinos Dimadis and Anastasia Lazaridou (Athens: Ellinika Grammata, 1999),

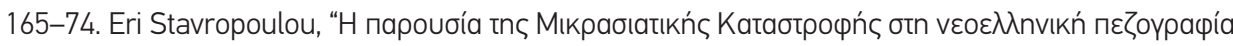

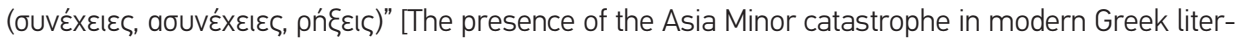
ature: continuities, discontinuities and ruptures], (paper presented at the 5th European Congress of Modern Greek Studies. Thessaloniki, 2-5 Oct. 2014), accessed 10 Apr. 2017, http://www.eens.org/ EENS_congresses/2014/stavropoulou_eri.pdf.

24 Peter Mackridge, "Kosmas Politis and the literature of exile," Deltio Kentrou Mikrasiatikon Spoudon 9 (1992): 223-39.

25 On this process, see Joseph Horowitz, Artists in exile: how refugees from twentieth-century war and revolution transformed the American performing arts (New York: Harper, 2009). Specifically in the Greek case, there have been objections regarding the limits between refugee literature (which is mainly realistic) and modernism. See Mackridge, "Kosmas Politis." On the other hand, the insistence on more traditional approaches by authors who had themselves experienced the war and who used novels to 
transmit their experience is not at all unknown in the literary production in other European countries

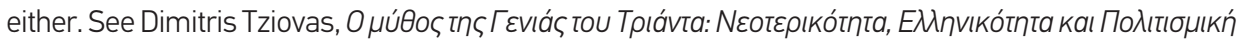

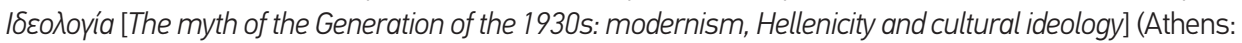
Polis, 2011), 74.

26 Antonis Liakos, "Multiple paths to citizenship: T.H. Marshall's theory and the Greek case," in Citizenship in Historical Perspective, ed. Steven Ellis, Guðmundur Hálfdanarson and Ann Katherine Isaacs (Pisa: Plus, 2006), 65-70.

27 The concept of postmemory describes the relation developed towards a traumatic event by a generation that has not experienced it directly, but only through the narrations and other kind of intermediations by the generation that experienced it. Cultural memory describes the collective memory of a social group or subculture (but even the dominant memory, according to Jan and Aleida Assmann). For this topic, see Jan Assmann, Das kulturelle Gedächtnis: Schrift, Erinnerung und politische Identität in früheren Hochkulturen (Munich: CH Beck, 1997); Aleida Assmann, Der lange Schatten der Vergangenheit: Erinnerungskultur und Geschichtspolitik (Munich: CH Beck, 2006); Marianne Hirsch, Family frames: photography, narrative, and postmemory (Cambridge: Harvard University Press, 1997); Andreas Huyssen, Present pasts: urban palimpsests and the politics of memory (Stanford: Stanford University Press, 2003).

28 In this period novels acquired a political and nostalgic, as well as an autobiographical, character. See Maria Nikolopoulou, "Space, memory and identity: the memory of the Asia Minor space in Greek novels of the 1960s," CAS Sofia Working Paper Series 1 (2007): 1-18.

29 Nevertheless, different perceptions of the past based on the National Schism were apparent in the way the decade was historiographically configurated for decades, even as late as 1962, when the first public commemorations of the war decade were held (50th anniversary of the Balkan Wars and 40th anniversary of the Asia Minor Catastrophe). Of special interest are the articles published in the To Vima

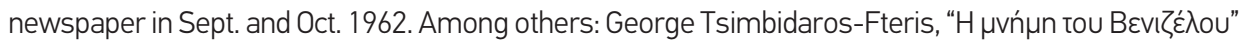

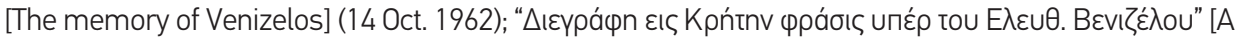

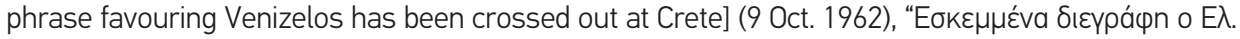

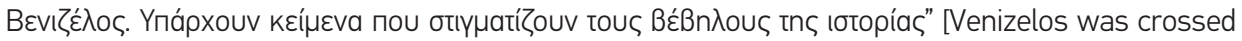
out on purpose. Texts stigmatise the profane of history"] (11 Oct. 1962), Enosis Kentrou, "Avakoívwon

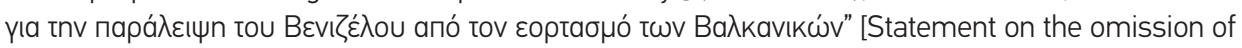
Venizelos from the commemoration of the Balkan Wars] (9 Oct. 1962).

30 Penelope Papailias, Genres of recollection: archival poetics and modern Greece (New York: Palgrave Macmillan, 2005), 96-98.

31 Antonio Gramsci, Selections from the prison notebooks (New York: International Publishers, 1971).

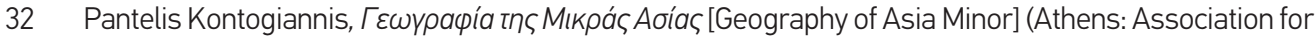
the Dissemination of Useful Books, 1921).

33 Kåre Johan Mjør, Reformulating Russia: the cultural and intellectual historiography of Russian first-wave émigré writers (Leiden: Brill, 2011).

34 On restorative nostalgia, see Svetlana Boym, The future of nostalgia (New York: Basic, 2001), 42-43.

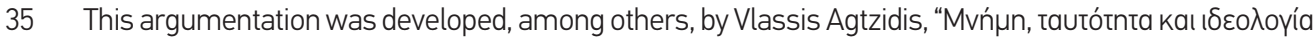

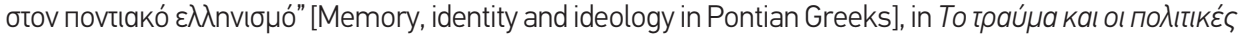

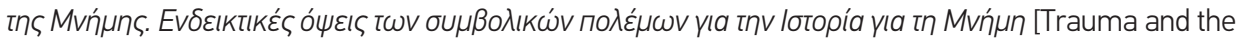
politics of memory: indicative aspects of the symbolic wars on history and memory], ed. Giorgos Kokkinos, Vlassis Agtzidis and Elli Lemonidou (Athens: Taxideftis, 2010), 191-329. For a critical overview of the issue of politicisation of memory, see Harris Exertzoglou, "Mvńun kaı Гevoktovía: H avarvúpıon 


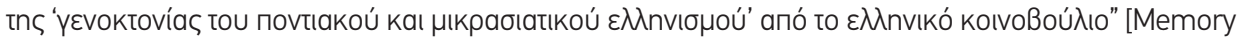
and genocide: the recognition of the "genocide of the Pontic and Asia Minor Greeks" by the Greek parliament"], in the CD that accompanied Historein 4 (2003-2004): 1-18. Also, Erik Sjöberg, The making of the Greek genocide: contested memories of the Ottoman Greek catastrophe (New York: Berghahn, 2017).

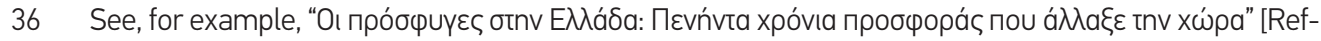
ugees in Greece: fifty years of a contribution that changed the country], O Oikonomikos Taxydromos (26 Apr. 1973), 992-31.

37 Exertzoglou, "Mvńun kaı 「عvoktovía."

38 On the way historiography evolved during the last quarter of the 20th century, see Antonis Liakos, "H

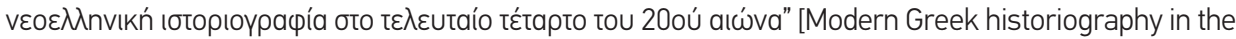
last quarter of the 20th century], Synchrona Themata 76-77 (2001): 72-91.

39 In the same period, continuities with the previous historiographical paradigm are still apparent. See,

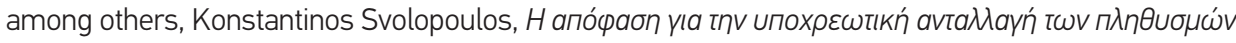

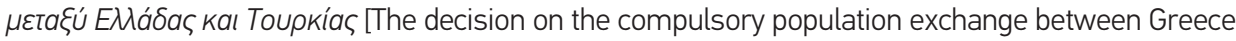
and Turkey] (Thessaloniki: Society for Macedonian Studies, 1981) and Angelos Tsouloufis, $\mathrm{H}$ avtaMa-

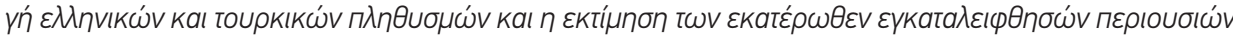
[The exchange of Greek and Turkish population and the evaluation of the properties left behind by both sides] (Athens: Enosis Smyrneon, 1989).

40 Early attempts include Renée Hirschon, ed., Crossing the Aegean: an appraisal of the 1923 compulsory population exchange between Greece and Turkey (New York: Berghahn, 2003); Müfide Pekin, ed. Yeniden Kurulan Yaşamlar: 1923 Türk Yunan Zorunlu Nüfus Mübadelesi (Istanbul: Istanbul Bilgi University, 2005);

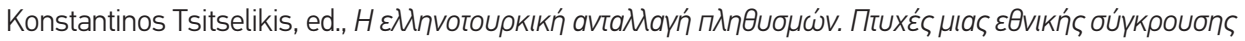
[The Greek-Turkish population exchange: aspects of a national clash] (Athens: Kritiki, 2006).

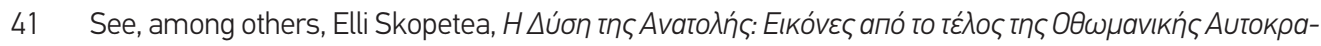
topías [The west/dusk of the east/dawn: images from the end of the Ottoman empire] (Athens: Gno-

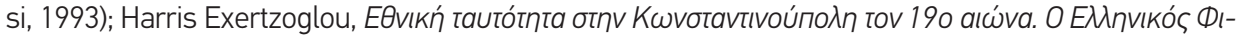

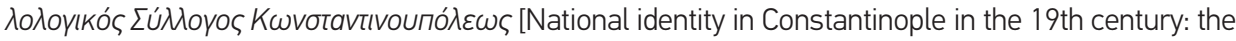
Greek Philosophical Society of Constantinople] (Athens: Nefeli, 1996); Sia Anagnostopoulou, Mikpá Aбía 19o aı

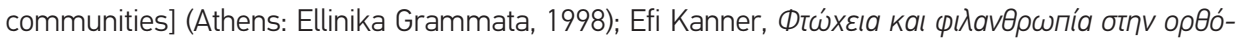

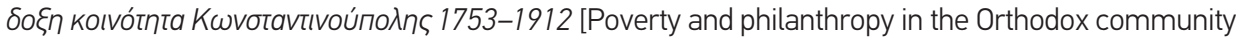
of Constantinople, 1753-1912] (Athens: Katarti, 2004); Vasilis Gounaris and lakovos Michailidis, eds.,

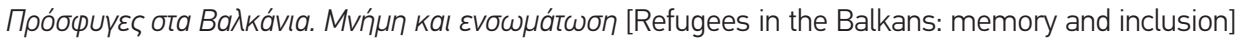

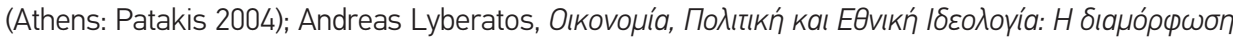

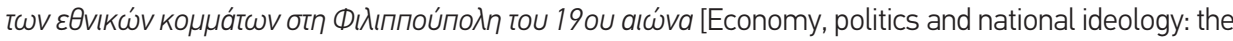
shaping of the national parties in 19th-century Philippopolis] (Irakleio: Crete University Press, 2009); Nikiforos Diamandouros, Thalia Dragonas and Cağlar Keyder, eds., Spatial conceptions of the nation. modernizing geographies in Greece and Turkey (London: IB Tauris, 2010); Benjamin C. Fortan, Stefanos Katsikas, Dimitris Kamouzis and Paraskevas Konortas, eds., State nationalisms in the Ottoman empire, Greece and Turkey (London: Routledge, 2013).

42 See, among others, Effi Gazi, “'Farewell Asia Minor': writing and telling the history of the Asia Minor war," paper presented at the 2nd Meeting on Mediterranean Societies, European University Institute,

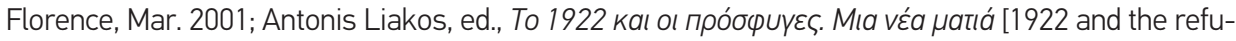
gees: a new approach] (Athens: Nefeli, 2011). 